\title{
Межведомственный круглый стол с международным участием «Проблемы следственной, экспертной практики и пути их решения»
}

\author{
А. В. Коряковцев
}

\author{
ЭКЦ ГУ МВД России по Алтайскомукраю \\ ул. Молодежная, 3, 656015, Барнаул, Россия. E-mail: che8383@ mail.ru
}

24 октября 2019 года в Барнаульском юридическом институте Министерства внутренних дел Российской Федерации состоялся межведомственный круглый стол с международным участием «Проблемы следственной, экспертной практики и пути их решения». Предметом обсуждения стали вопросы назначения, производства и последующего применения экспертиз по материалам, содержащим признаки преступлений против чести и достоинства личности. Входе круглого стола были рассмотрены вопросы, касающиеся предварительной работы следователя, дознавателя, участкового уполномоченного полиции с материалами, содержащими признаки клеветы, оскорбления, их доэкспертной оценки при назначении лингвистических экспертиз и исследований. Участники круглого стола обсудили меры по повышению эффективности использования специальных лингвистических знаний в ходе раскрытия и расследования преступлений, а также возможности сокращения сроков производства лингвистических экспертиз и исследований.

Ключевые слова: лингвистическая экспертиза, честь и достоинство личности, оскорбление, клевета.

\section{Interdepartmental Round-Table Discussion with International Participation "Challenges of Investigative, Expert Work and Ways to Address Them"}

\author{
A. V. Koryakovtsev \\ Directorate for Criminal Investigation of the Ministry of Internal Affairs \\ of the Russian Federation in Altai Krai \\ Molodezhnayast. 3, 656015, Barnaul, Russia.E-mail:che8383@mail.ru
}

\begin{abstract}
Barnaul University of the Russian Interior Ministry hosted interdepartmental round-table discussion with international participation "Challenges of Investigative, Expert Work and Ways to Address them" on October 24, 2019. The subject of discussions was commissioning, production and subsequent administration of expert evidence to the cases containing signs of offense against human honor and dignity. The round table discussion concerned preliminary work of the investigator, the interrogator, and the district police officer with the materials containing elements of slander and insults, their pre-expert assessment before commissioning linguistic analysis. The participants of the round table discussion considered measures to improve the efficien cy of the use of special linguistic knowledge in the process of investigation and clearing of crimes, as well as the possibility of reducing the time of production of forensic analysis.

Key words: linguistic analysis, human honor and dignity, insult, slander.
\end{abstract}

24 октября 2019 года в Барнаульском юридическом институте Министерства внутренних дел Российской Федерации состоялся межведомственный круглый стол с международным участием «Проблемы следственной, экспертной практики и пути их решения». Предметом обсуждения стали вопросы назначения, производства и последующего применения экспертиз по материалам, содержащим признаки преступлений против чести и достоинства личности.

В ходе круглого стола были рассмотрены вопросы, касающиеся предварительной работы следователя, дознавателя, участкового уполномоченного полиции с материалами, содержащими признаки клеветы, оскорбления, их доэкспертной оценки при назначении лингвистических экспертиз и исследований. Собравшиеся обсудили меры по повышению эффективности использования специальных лингвистических знаний в ходе раскрытия и расследования преступлений, а также возможности сокращения сроков производства лингвистических экспертиз и исследований.

Пристальное внимание на семинаре было уделено обсуждению особенностей интернет-среды в связи с распространением информации, порочащей честь и достоинство личности. Воплощению преступного умысла способствуют следующие особенности интернет-среды. 
Интернет создает неограниченные возможности для анонимного (псевдонимного) распространения информации. Это порождает использование псевдонимных аккаунтов лицами, осуществляющими публикацию, для сокрытия личности. Частым видом правонарушения становится опубликование порочащей информации в виде объявления с рекламой услуг от имени другого лица (например, размещение рекламного объявления об оказании интимных услуг третьим лицом от его имени, с указанием его контактных данных).

Интернет-среда является наиболее эффективным инструментом публичного распространения информации. На сегодняшний день Интернет стоит признать самым доступным и дешевым средством массовой информации.

Интернет открыл возможность ухода от классического, непосредственного способа распространения информации, коим являлось размещение в общественных местах листовок, печатных изданий, плакатов; распространение информации в ходе публичных выступлений. В современном мире информация размещается виртуально - на форуме, в тематических группах, в новостной ленте, рассылается группе пользователей.

Наконец, Интернет-среда позволяет мгновенно распространить информациюдля определенной целевой (подписчики группы в социальной сети, участники чата в мессенджере типа «WhatsApp», «Telegram») или неопределённой аудитории (читатели новостных ресурсов, участники социальной сети).

На семинаре было отмечено, что в общем числе лингвистических экспертиз, поступивших в эКц ГУ МВД России по Алтайскому краю в 2018 и 2019 годах, назначенных по признакам преступлений против чести и достоинства личности, наблюдается планомерный рост количества объектов-текстов, размещённых в публичном доступе в среде интернет-коммуникации. По итогам 2018 года количество таких объектов составило более 70\% от общего числа материалов по составам «клевета», «оскорбление», а на текущий период 2019 года превысило 80\%, что указывает на выраженную тенденцию роста количества предоставляемых на исследование текстов, распространяемых в интернет-среде.

Большинство материалов на экспертизу или исследование назначается участковыми уполномоченными, а также представителями дознания по инициативным обращениям граждан. Анализируемые тексты предоставляются на исследование как правило в виде скриншотов (снимков экрана интернет-страниц, программ мгновенного обмена сообщениями).

Анализ представляемых на исследование объектов позволяет выделить наиболее типичные формы распространения информации, порочащей честь и достоинство личности, в интернет-среде:

- тексты размещаются в виде рекламных объявлений (в тематических группах, на страницах в социальных сетях);

- в группах социальной сети, специально предназначенных для размещения негативной информации олицах;

- в форме комментариев в тематических группах социальных сетей, на форумах, новостных и иных ресурсах;

- информации в виде негативных отзывов на ресурсах типа «Фламп», «Отзовик».

В интернет-среде сформировались наиболее типичные способы адресного распространения негативной информации о лице: например, в виде адресной рассылки пользователям социальной сети, находящимся в "друзьях» с лицом, в отношении которого распространяется информация; рассылки множеству пользователей программ мгновенного обмена сообщениями и др. В то же время докладчики семинара отмечали, что формы реализации и способы распространения негативной информации в интернете постоянно видоизменяются. К примеру, может быть заведён аккаунт от имени лица, которое нужно опорочить, содержащий негативную информацию о нём. Ещё вариант: третье лицо регистрирует один аккаунт с именем пользователя-женщины «А», другой аккаунт с именем пользователя-мужчины «Б», между ними моделируется переписка, например, содержащая предложение “А» оказать “Б» интимные услуги. Затем скриншоты смоделированной переписки фейковых аккаунтов распространяются в интересах создавшего их лица.

В связи с особенностями текстов, реализуемых в интернет-среде, содержащих признаки составов преступления по ст. 128.1 УК РФ («Клевета»), 319 УК РФ («Оскорбление представителя власти»), ст. 5.61 КоАП («Оскорбление»), инициатору назначаемых на исследование материалов во взаимодействии с экспертом было решено рекомендовать на предварительном этапе работы обратить внимание на:

- разборчивость текста (имеющиеся нечитаемые фрагменты могут затруднять смысловое понимание);

- полноту предоставления объектов для доказывания события преступления (соблюдение принципов «достаточности» и «умеренности»). Так, для решения вопросов состава «оскорбление» («Имеются ли в представленном тексте высказывания, в которых в данной коммуникативной ситуации негативно оценивается гр. Х? Если да, то какими средствами выражена данная оценка, имеется ли ее обоснование?»), «клевета» («Имеются ли в представленном тексте высказывания, в которых получили речевое выражение какиелибо факты действительности или положения дел, имеющие отношение к гр. X и выражающие негативную оценку его деятельности? Если да, то в какой форме они представлены? Имеются ли ссылки на какой-либо источник информации?») необходим достаточный контекст, позволяющий всесторонне проанализировать объект, в то же время факт (факты), в связи с которыми необходимо произвести исследование, должны быть конкретизированы;

- наличие информации о ситуации публикации текста (имеются ли реквизиты размещения: дата, время; формальные указания на конкретное место размещения (форум, чат мессенджера, тематическая группа социальной сети; имя пользователя, разместившего текст);

- наличие в тексте указаний на лицо (имя, фамилия, иная номинация), обратившееся с заявлением.

Таким образом, учёт всех указанных особенностей взаимодействия инициатора экспертизы (исследования) и эксперта позволит повысить эффективность расследования преступлений против чести и достоинства личности.

\section{Citation:}

Коряковцев, А.В. Межведомственный круглый стол с международным участием «Проблемы следственной, экспертнойпрактики и пути их решения». // Юрислингвистика. - 2019.- 14. - С. 22-23.

Koryakovtsev, A. V. (2019 Interdepartmental Round-Table Discussion with International Participation “Challenges of Investigative, Expert Work and Ways to Address them". Legal Linguistics, 14, 22-23.

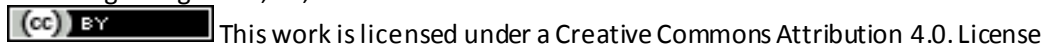

